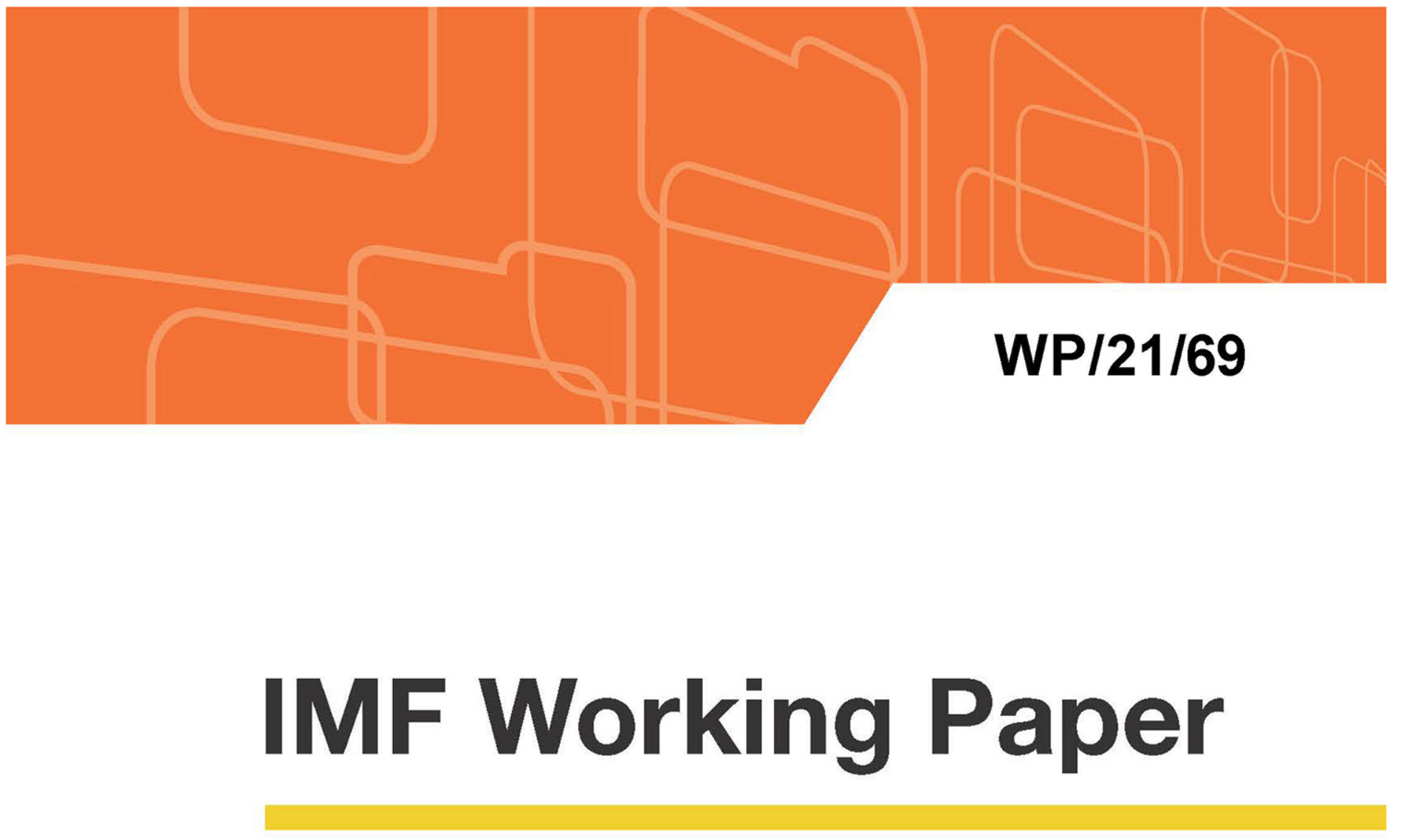

\title{
Sizing Up the Effects of Technological Decoupling
}

by Diego A. Cerdeiro, Johannes Eugster, Rui C. Mano, Dirk Muir, and Shanaka J. Peiris

IMF Working Papers describe research in progress by the author(s) and are published to elicit comments and to encourage debate. The views expressed in IMF Working Papers are those of the author(s) and do not necessarily represent the views of the IMF, its Executive Board, or IMF management. 


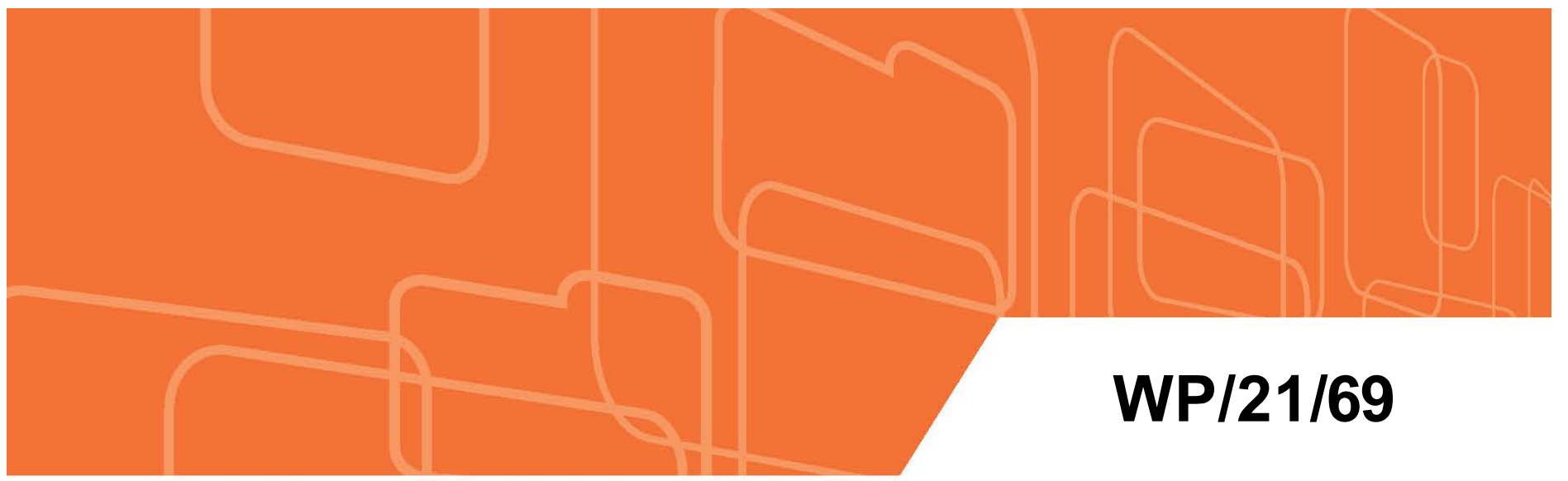

\section{IMF Working Paper}

\section{Sizing Up the Effects of Technological Decoupling}

by Diego A. Cerdeiro, Johannes Eugster, Rui C. Mano, Dirk Muir, and Shanaka J. Peiris

IMF Working Papers describe research in progress by the author(s) and are published to elicit comments and to encourage debate. The views expressed in IMF Working Papers are those of the author(s) and do not necessarily represent the views of the IMF, its Executive Board, or IMF management.

I N T E R N A T I O N A L M O N E T A R Y F U N D 


\title{
IMF Working Paper
}

Asia and Pacific Department

Strategy, Policy, and Review Department

\section{Sizing Up the Effects of Technological Decoupling ${ }^{1}$}

\section{Prepared by Diego A. Cerdeiro, Johannes Eugster, Rui C. Mano, Dirk Muir and Shanaka J. Peiris}

Authorized for distribution by Helge Berger

March 2021

\section{IMF Working Papers describe research in progress by the author(s) and are published to elicit} comments and to encourage debate. The views expressed in IMF Working Papers are those of the author(s) and do not necessarily represent the views of the IMF, its Executive Board, or IMF management.

\begin{abstract}
This paper proposes channels through which technological decoupling can affect global growth, and embeds these different layers in a global dynamic macroeconomic model. Multiple scenarios are considered that differ along two dimensions: (i) the coalition of countries (hubs) that initiate the decoupling, and (ii) whether non-hub countries are also forced to decouple via 'preferential attachment' - i.e. by aligning themselves with the hub they trade most with. All global technology hubs lose across scenarios, and losses are largest under preferential attachment. Smaller countries with relations that straddle multiple hubs generally lose, whereas those whose trade is heavily concentrated with one hub may gain due to reduced competition under some scenarios. Technological fragmentation can lead to losses in the order of 5 percent of GDP for many economies.
\end{abstract}

JEL Classification Numbers: F12, F13, F17, F43, E37, O31.

Keywords: Technological decoupling, trade, non-tariff barriers.

Author's E-Mail Addresses: dcerdeiro@,imf.org; Johannes.eugster@snb.ch; rmano@imf.org; dmuir@imf.org; speiris@imf.org

\footnotetext{
${ }^{1}$ We a re grateful to Helge Berger for insightful discussions that helped shape the paper. We are also grateful to Chris Erceg, Daniel Garcia-Macia, Gita Gopinath, Rishi Goyal, Kenneth Kang, Martin Kaufman, Malhar Nabar, Papa N'Dia ye, Jonathan D. Ostry, Chang Yong Rhee, and IMF seminar participants for their helpful comments. All errors a re ours.
} 


\section{Introduction}

Technological decoupling — broadly defined as the undoing of cross-border trade in high-tech goods and services - has been associated with concerns about intellectual property protection, data privacy, and national security concerns as well as a renewed attention to industrial policies. However, surprisingly little is known about what such strategies might entail for the affected economies. News reports have highlighted the political economy motivations for decoupling and mapped out the unravelling of ties (Webster, 2020), with few attempts to quantify their economic impacts. The academic literature has so far focused predominantly on theoretical aspects of technological decoupling (Garcia-Macia and Goyal, 2020 and references therein) and innovation and research and development (R\&D) spillovers (Cai and others, 2019). This paper aims to help fill this gap by providing a taxonomy of channels through which decoupling can affect economic activity and embedding these different layers in a global quantitative macroeconomic model to assess the effects of various scenarios.

Barriers to trade in high-tech sectors between major economies could have profound effects on world production and consumption patterns because they affect some of the fastest growing sectors in most economies and high-tech production is heavily dependent on cross-border trade. For example, the share of foreign value added in gross exports in the electronics sector is significantly higher than for all other sectors, especially in Asia (Figure 1).
Figure 1. Interdependent High-Tech (share of foreign value added in gross exports, 2015 , in percent)

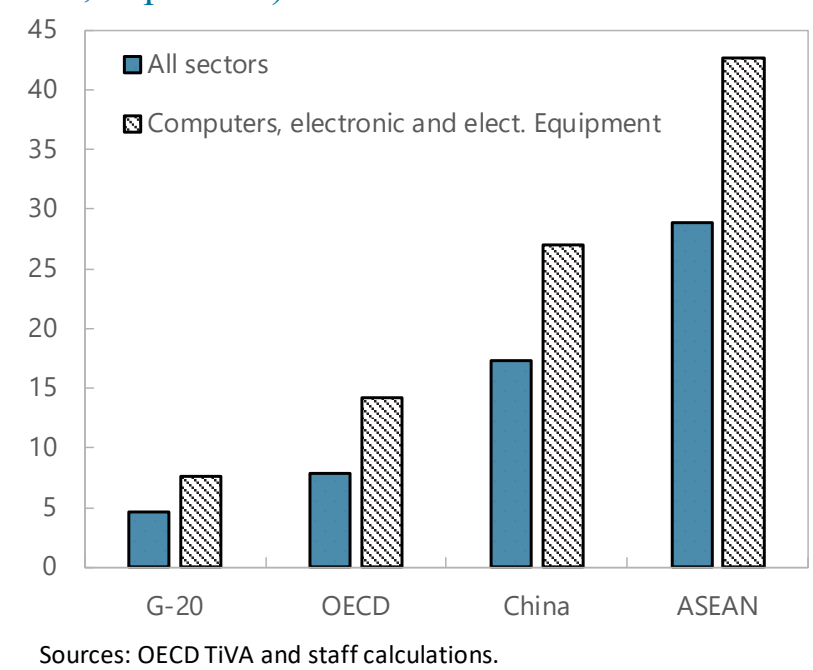

This suggests that barriers to trade in high-tech sectors through tariffs or non-tariff measures have the potential to reverberate throughout the global economy. Other forms of restriction such as those on participation in $5 \mathrm{G}$ infrastructure or access to software and patents limit 
technological diffusion and spillovers through associated research and development and foreign direct investment.

To help quantify the economic effects of technological decoupling, this paper considers three possible channels, focusing on the production and trade of goods that are themselves reliant on innovative intellectual property, particularly in information and communication technology sectors ("high-tech" goods).

- The short- and long-term reduction in global trade flows, whereby rival countries impose higher non-tariff barriers (NTBs) to eliminate the relative demand for high-tech imports, a direct effect that is compounded by domestic investment and consumption responses to the resulting permanent income losses. ${ }^{2}$ These effects are quantified using the IMF's Global Integrated Monetary and Fiscal model (GIMF).

- The long-term impact on output of sectoral misallocation, that is, the less efficient allocation of resources across sectors as trade is cut off between hubs and blocs. These effects are quantified using a sectoral, computable general equilibrium trade model which estimates these effects (Caliendo, Feenstra, Romalis, and Taylor, 2017; CFRT henceforth).

- The short- and long-term dynamics losses because of the effect of lower foreign knowledge diffusion on domestic labor productivity. These effects are derived empirically from data on patents, R\&D spillovers, and their productivity effects among technological leaders. Estimates, originally produced for IMF (2018a), are extended here to also include China and Korea.

These three channels are combined into one coherent presentation in GIMF taking into account dynamic global general equilibrium effects, capturing the shifts in trade computed using GIMF, the shifts in economy-wide labor productivity because of sectoral misallocation initially

\footnotetext{
${ }^{2}$ The imposition of NTBs to virtually eliminate trade in technological goods is assumed to proxy any type of measure taken to restrict their tra de on national security grounds or other protectionist motives. The use of tariffs is another a lternative a pproach that has been extensively modeled in IMF (2018b) and (2018c). Tariffs differ from NTBs in that they generate revenues for governments in a ddition to generating costs for consumers, which is not an accurate representation of technological decoupling a s presented in this paper.
} 
computed from CFRT, and the shifts in tradable sector labor productivity because of lower knowledge diffusion computed from the estimates based on patents and R\&D data. ${ }^{3}$

To be sure, this paper does not capture all possible mechanisms through which policies aimed at technological decoupling may affect economic activity. The effects of decoupling through lower FDI flows are not explicitly modeled, nor are those from the provision of foreign services through commercial presence. ${ }^{4}$ Also not modeled is the potential endogenous nonmacroeconomic policy response to decoupling, such as industrial policies that aim to make up for the loss of access to foreign technology. Lastly, technological decoupling can over time give rise to diverse, incompatible standards. Diverging standards could effectively lock in the losses uncovered in this paper, as reversing the decoupling (or "re-coupling") would become increasingly difficult (see the pioneering discussion by David, 1985).

Table 1. Hypothetical Technological Decoupling Scenarios

\begin{tabular}{ccc} 
Scenario \# & Global hubs & $\begin{array}{c}\text { Preferential attachment by } \\
\text { non-hub countries? }\end{array}$ \\
\hline \hline 1 & China | U.S. & No \\
2 & China | OECD \\
3 & No \\
4 & Yes \\
5 & China | U.S. | Germany \\
6 & Yes \\
\hline Notes: In all scenarios, non-tariff barriers are raised so as to nearly eliminate \\
trade in high-tech sectors. \\
Source: Authors' calculations
\end{tabular}

\footnotetext{
${ }^{3}$ As will become clear when showing the simulation results, a ll economies tend to lose out through these channels as a result of decoupling. This is consistent with the view that the main rationales behind the a im to decouple have been mostly non-economic, involving issues such as national security, data privacy, etc. This view is supported by many industry groups expressing concern a bout the restrictions in high-tech trade (for the U.S. see, e.g., U.S.-China Business Council, 2021; U.S. Chamber of Commerce, 202 1; and the a nalysis of Bown, 2020 on theU.S. semiconductor industry). See Garcia-Macia and Goyal(2020) for a model where decoupling a rises from economic incentives.

${ }^{4}$ Other tha n tourism and tra nsport, services as recorded in input-output matrices a re la rgely non-tradable. Services provided under mode 3 (commercial presence; e.g. telecoms) belong to domestic production, in line with national accounting practices. Some services related to certain technology ga ins are partly and indirectly modeled through our knowledge-diffusion channel, to the extent that they are reflected in patent a nd R\&D data.
} 
In addition to the specific channels through which technological decoupling operates, there is the question of which countries it affects. Three very stylized and hypothetical alternatives of technological decoupling are considered in this paper (Table 1). The first, and most prominent in recent discussions, is the possibility of a China-U.S. decoupling. The second is one where OECD economies as a bloc decouple from China. The third is a multipolar world of three technology hubs that decouple from one another. For the purposes of illustration only, the tripolar world considered here is formed around the United States, China, and Germany.

While the preceding discussion defines the technology hubs that would seek to decouple from one another, it still leaves open the question of how other non-hub countries would interact with each of the hubs. Two possibilities are considered - non-hub countries trade with each hub freely or they align themselves with the hub for which their total trade is highest and only trade with other countries in that bloc. The latter possibility is labeled "preferential attachment." 5

\section{The Three Channels of Decoupling}

This section discusses the detailed analytical work used to quantify the reduction in global trade volumes, sectoral misallocation, and lower knowledge diffusion in turn.

\section{a. Reduction in Global Trade Flows}

The first order impact from technological decoupling (modeled as effective barriers to trade) is the associated fall in exports between the different hubs and their associated trade blocs. The short- and long-term macroeconomic impacts of the cessation of exports concentrated in the high-tech sectors is captured using GIMF, a global overlapping-generations dynamic stochastic general equilibrium (DSGE) model. ${ }^{6}$ To contain the scale of the model, which features rich dynamic representations of all included economies, there are only eight countries or regions in

\footnotetext{
${ }^{5}$ For a concrete example of the tensions facing by some economies, see "U.S., China Shouldn'tForceOthers to Choose Sides: Morrison,"Bloomberg News, November 23, 2020.

${ }^{6}$ See Kumh of and others (2010) for a theoretical presentation of the model. See Anderson and others (2013) for a discussion of the model's properties. Appendix II discusses features unique to this version of GIMF not found in the aforementioned papers.
} 
GIMF - China, the United States, the euro area, India, Japan, and Korea, as well as two more blocs for the remainder of the Asia-Pacific region and the remaining countries.

\section{Figure 2. Reduction of Global Trade Flows: Real GDP for Selected Regions (Percent deviation from the IMF's October 2020 WEO)}

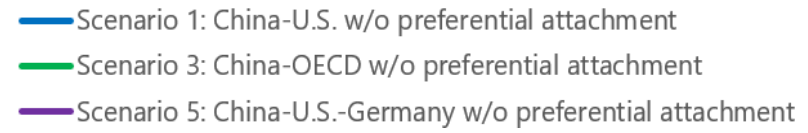

China

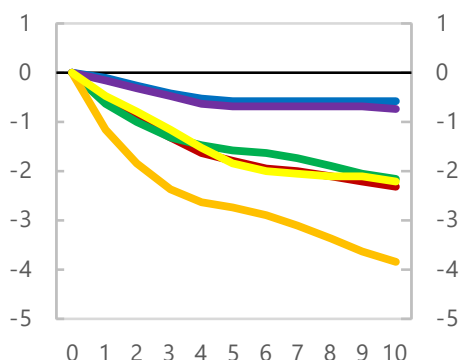

Years

India

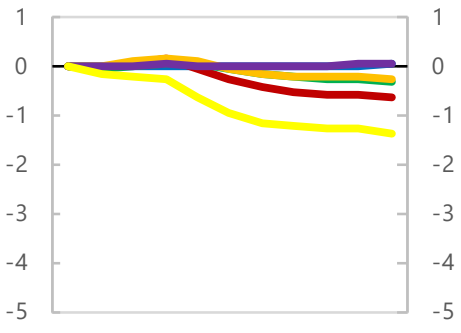

$\begin{array}{lllllllllll}0 & 1 & 2 & 3 & 4 & 5 & 6 & 7 & 8 & 9 & 10\end{array}$

Years
United States

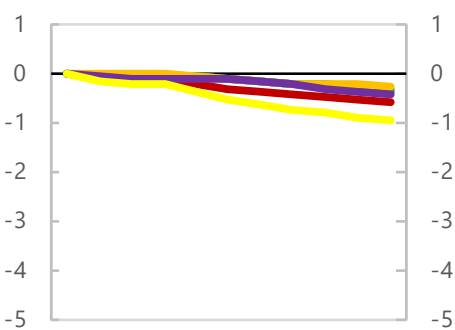

$\begin{array}{lllllllllll}0 & 1 & 2 & 3 & 4 & 5 & 6 & 7 & 8 & 9 & 10\end{array}$

Years

Japan

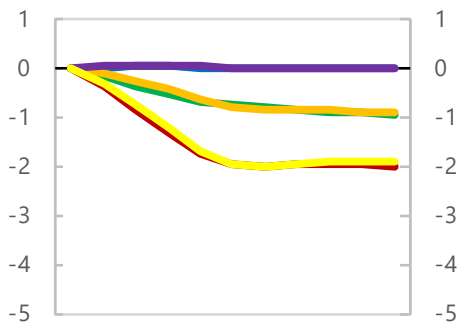

$\begin{array}{llllllllllll}0 & 1 & 2 & 3 & 4 & 5 & 6 & 7 & 8 & 9 & 10\end{array}$

Years
Scenario 2: China-U.S. with preferential attachment

Scenario 4: China-OECD with preferential attachment Scenario 6: China-U.S.-Germany with preferential attachment

Source: Authors' calculations.

It is assumed for the six scenarios that countries impose NTBs to eliminate all bilateral imports in high-tech consumption, investment and intermediate goods based on the long-term magnitudes from CFRT (discussed below), but allowing for long-term adjustments in current accounts and net foreign asset positions, which are only possible in GIMF. When, for example, the United States imposes NTBs against Chinese goods, both countries experience negative impacts (Figure 2). China loses an export market, and loses income, which has negative impacts on its firms who invest less and hire less. The fall in employment has an impact on households, who then consume less, which further shrinks the economy. China may also reduce the price of its goods subject to NTBs to increase market share elsewhere in the world. In the United States, the fall in 
imports from China will increase demand for goods from other countries (cause trade diversion), which will likely be more expensive than the foregone Chinese goods, thereby increasing inflation in the short term, but also reducing investment and consumption, as the fewer goods can be purchased for the same level of income initially, which will also drive a fall in U.S. output. Non-hub countries can either gain from trade diversion or lose from negative spillovers as the Chinese and U.S. economies contract.

Trade can cause myriad spillovers among countries, as the six scenarios represent not just U.S. NTBs on China, but different constellations of NTBs among all countries, with preferential attachments or otherwise. The United States losses are relatively smaller, at least in part due to being a relatively more closed economy. Even so, it stands to lose around half a percent of GDP or more permanently across scenarios. China's losses are higher, most notably in the scenarios where most of its high-tech links are affected (scenario 4). While trading most with China, Japan and Korea also have strong links with both the United States and Europe, so they lose substantially in the preferential attachment scenarios 2 and 6.

\section{b. Sectoral Misallocation}

Given the varying degrees of technological intensity across sectors, technological decoupling is intrinsically a sectoral shock. To understand its effects, it is useful to capture the productivity losses from a less efficient allocation of resources across sectors and countries by employing CFRT, the computable general equilibrium model by Caliendo and others (2017), as calibrated in Caceres and others (2019).

CFRT captures two key features of the international production of goods and trade: (1) that firms within each sector are heterogeneous in their productivity, and (2) that input-output relationships have increasingly developed across borders, with intermediate goods dominating world trade flows. To model productivity effects, CFRT allows for endogenous firm entry and exit from domestic and export markets in response to shocks, a feature that can greatly amplify economic effects and allows for more drastic re-composition of global production. As to global supply links, the fact that production of any sector requires intermediate inputs from all other sectors 
explicitly in CFRT generates yet another amplification mechanism, as shocks reverberate across domestic and foreign production value chains.

Within this framework, the sectoral misallocation effects of technological decoupling are modeled through the imposition of high bilateral non-tariff barriers that represent the scenarios in Table 1. For each scenario, the effect of changes in NTBs is simulated using input-output data covering 165 countries and a total of 17 sectors (see Appendix I for details). High-tech sectors are identified based on the classification in OECD (2011), which is based on sectoral R\&D intensities. This suggests two high-tech sectors: electronics and machinery (denoted as "electronics" henceforth), and transport equipment. Decoupling is then simulated by raising NTBs in high-tech sectors so as to virtually eliminate relevant bilateral trade in those sectors. ${ }^{7}$

Table 2. Sectors: Technological Intensity and Elasticities

\begin{tabular}{clcc}
\hline Sector \# & Simplified sector name & Elasticities 1/ & Tech-intensity 2/ \\
\hline 1 & Agriculture, Hunting, Forestry, and Fishing & 9.1 & N.A. \\
2 & Extractive Industries & 19.0 & N.A. \\
3 & Food, Beverages, and Tobacco & 2.5 & Low \\
4 & Textiles, Textile Products, Leather, and Footwear & 3.0 & Low \\
5 & Wood, Paper, Printing, and Publishing & 5.4 & Low \\
6 & Petroleum, Chemical, Non-Metallic Mineral Products & 12.1 & Medium-Low ${ }^{3 /}$ \\
7 & Metal Products & 13.9 & Medium-Low \\
8 & Electrical Equipment and Machinery & 2.6 & Medium-High \\
9 & Transport Equipment & 8.0 & Medium-High \\
10 & Other Manufacturing; Recycling & 4.0 & Low \\
\hline
\end{tabular}

Sources: Caceres and others (2019), OECD (2011), a nd authors' calculations.

Notes: 1/ See Table 2 in Caceres a nd others (2019), column "Preferred". 2/ From OECD(2011). 3/ This sector a ggrega tes three ISIC revision 3.1 manufacturing sub-sectors listed as Medium-Low (Divisions 23, 25-26) and one listed as Medium-High (Division 24). 4/ This sector aggregates one ISIC revision 3.1 manufacturing subsectors listed a s Medium-High (Division 29) and another listed a s High (Divisions 30-33).

The necessary increase in NTBs to achieve such sectoral decoupling is inversely proportional to sectoral trade elasticities. Estimated sectoral trade elasticities are presented in Table 2 alongside

\footnotetext{
${ }^{7}$ By design, CFRT does not a llow for corner solutions (see Caceres a nd others, 2019, for a discussion). In all simula tions, therefore, the aim is to reduce trade in high-tech sectors by at lea st 95 percent.
} 
the technological intensities discussed above. Given the different elasticities for high-tech sectors, achieving decoupling as defined above ends up entailing doubling NTBs for trade in transport equipment, and quadrupling them for trade in electronics. For services, an elasticity of 5 is assumed following Caceres and others (2019). The technological intensity classification in OECD (2011) does not include services and thus they are not considered in the scenarios.

Table 3 presents the simulated changes in output (panel (a)) and real exports (panel (b)) for each scenario for selected countries. Since these output changes reflect the change in levels between steady states, they are best interpreted as the expected long-term or "potential" output effects of decoupling.

Table 3. Simulated Effects: Selected Economies

(a) Potential output

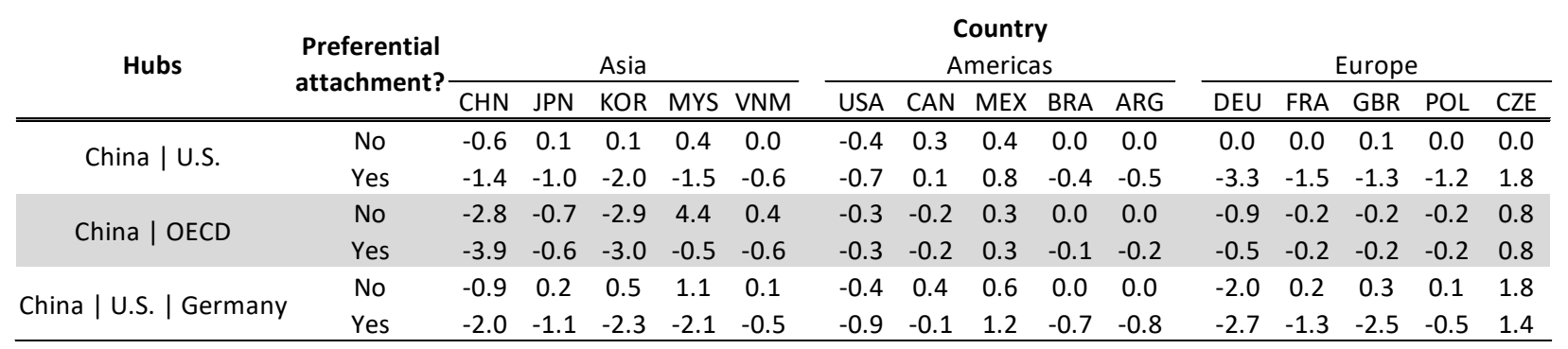

(b) Real exports

\begin{tabular}{|c|c|c|c|c|c|c|c|c|c|c|c|c|c|c|c|c|}
\hline \multirow[t]{2}{*}{ Hubs } & \multirow{2}{*}{$\begin{array}{l}\text { Preferential } \\
\text { attachment? }\end{array}$} & \multicolumn{15}{|c|}{$\begin{array}{c}\text { Country } \\
\text { Americas }\end{array}$} \\
\hline & & $\mathrm{CHN}$ & JPN & KOR & MYS & VNM & USA & CAN & MEX & BRA & ARG & DEU & FRA & GBR & $\mathrm{POL}$ & CZE \\
\hline \multirow{2}{*}{ China | U.S. } & No & -3.3 & 0.8 & -0.1 & 0.8 & -0.4 & -3.4 & 1.5 & 3.4 & 0.1 & 0.2 & 0.0 & 0.1 & 0.4 & 0.2 & 0.0 \\
\hline & Yes & -6.5 & -8.5 & -5.8 & 0.3 & 5.1 & -7.2 & 6.4 & 13.1 & -2.9 & -1.1 & -9.5 & -7.8 & -6.6 & -7.5 & 12.7 \\
\hline \multirow{2}{*}{ China | OECD } & No & -14.3 & -4.7 & 2.9 & 9.7 & -3.9 & -1.7 & -0.8 & 3.5 & 1.5 & 0.2 & -1.0 & -0.8 & -1.0 & -1.1 & 1.7 \\
\hline & Yes & -21.2 & -3.9 & 1.2 & 2.5 & 3.8 & -2.0 & -0.9 & 3.6 & -1.1 & -1.0 & -0.8 & -1.2 & -1.1 & -2.0 & 0.9 \\
\hline \multirow{2}{*}{ China | U.S. | Germany } & No & -4.6 & 2.2 & -1.4 & 1.5 & -3.9 & -3.5 & 2.9 & 6.5 & 1.7 & 0.6 & -2.5 & 1.6 & 1.7 & 1.4 & 5.4 \\
\hline & Yes & -10.0 & -10.4 & -9.0 & -1.2 & 6.1 & -8.4 & 8.5 & 20.7 & -4.8 & -0.5 & -5.9 & -5.0 & -11.5 & -0.6 & 6.5 \\
\hline
\end{tabular}

Source: Authors' calculations.

It can be readily seen that hubs tend to lose across scenarios. For China, the losses range between less than one percent in the level of potential output, to nearly 4 percent in the harsh China versus OECD scenario with preferential attachment. Whether a smaller country loses depends on its relationship with hubs: if it is mostly related to a single hub with which it can enjoy less thirdparty competition then it might gain through trade diversion (e.g. Mexico). If its value chains are 
built by straddling different regional value chains then it either benefits marginally or is more likely to lose (e.g., Korea).

The stark losses accruing to China in the preferential-attachment scenario versus OECD countries reflect the sheer size of the coalition of countries assumed to be engaging in technological decoupling from China. To illustrate this, Figure 3 shows the aggregate GDP of each bloc in the scenarios with preferential attachment. Because the OECD is such a large bloc, China is left nearly isolated in this hypothetical situation. In fact, only four out of 164 countries would trade more with China than with the OECD as a whole, so that China's bloc in this scenario would consist of only 5 (small) countries. In the other two scenarios with preferential attachment, on the other hand, the different blocs would be of far more similar size. Some hubs (China, Germany) lose more than others (the United States) in these scenarios mainly because they are relatively more open economies.

Figure 3. Aggregate GDP of Segmented Regions (US\$ trillion, scenarios with preferential attachment)
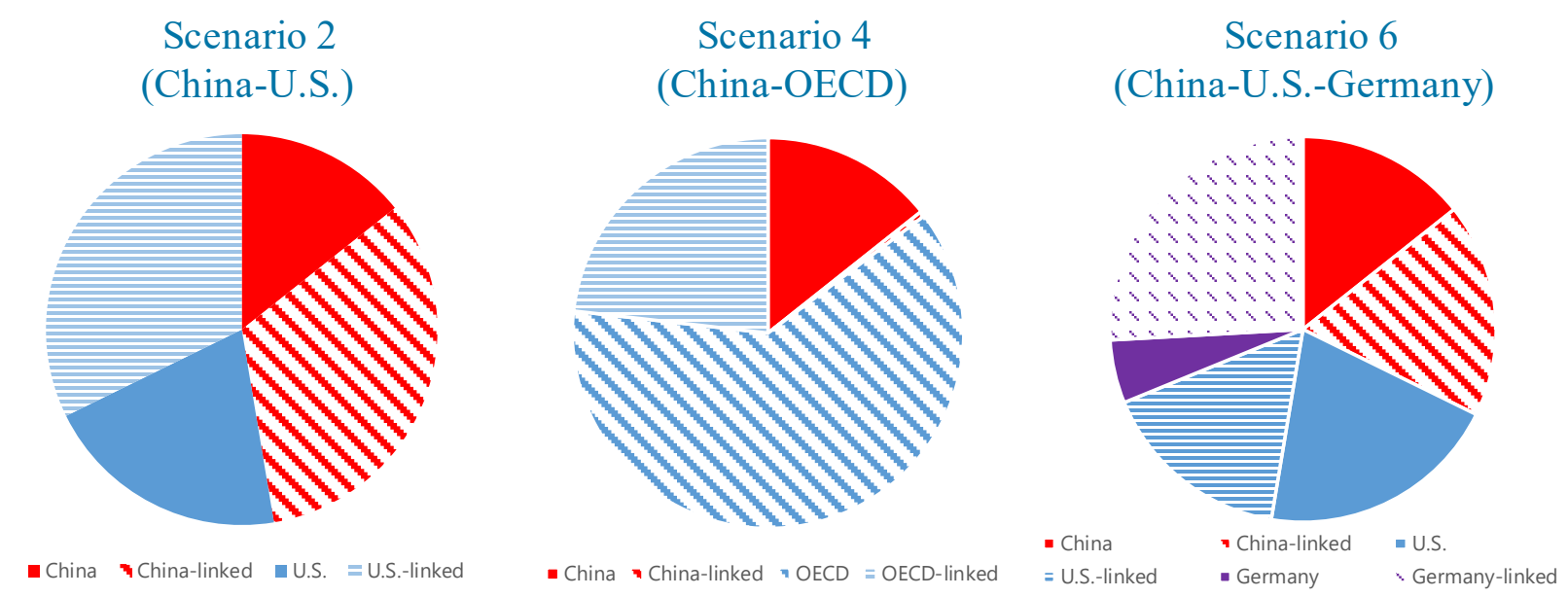

Source: Authors' calculations.

This layer of results is available for 165 countries. The color-coded maps in Figure 4 show the effects on potential GDP across the six scenarios. There are some interesting and intuitive effects on non-hub countries. For example, in scenario 5, Germany is cut off from trading with the United States and China in the two high-tech sectors, which benefits other European countries 
who begin to intermediate this trade given their proximity and close input-output linkages with Germany. When comparing scenarios with preferential attachment, losses are relatively more heavily concentrated in China under the isolationist China versus OECD scenario 4, and more widespread when the world is split in the more evenly distributed blocs of scenarios 2 and 6 .

Figure 4. Effect on Potential GDP Around the World

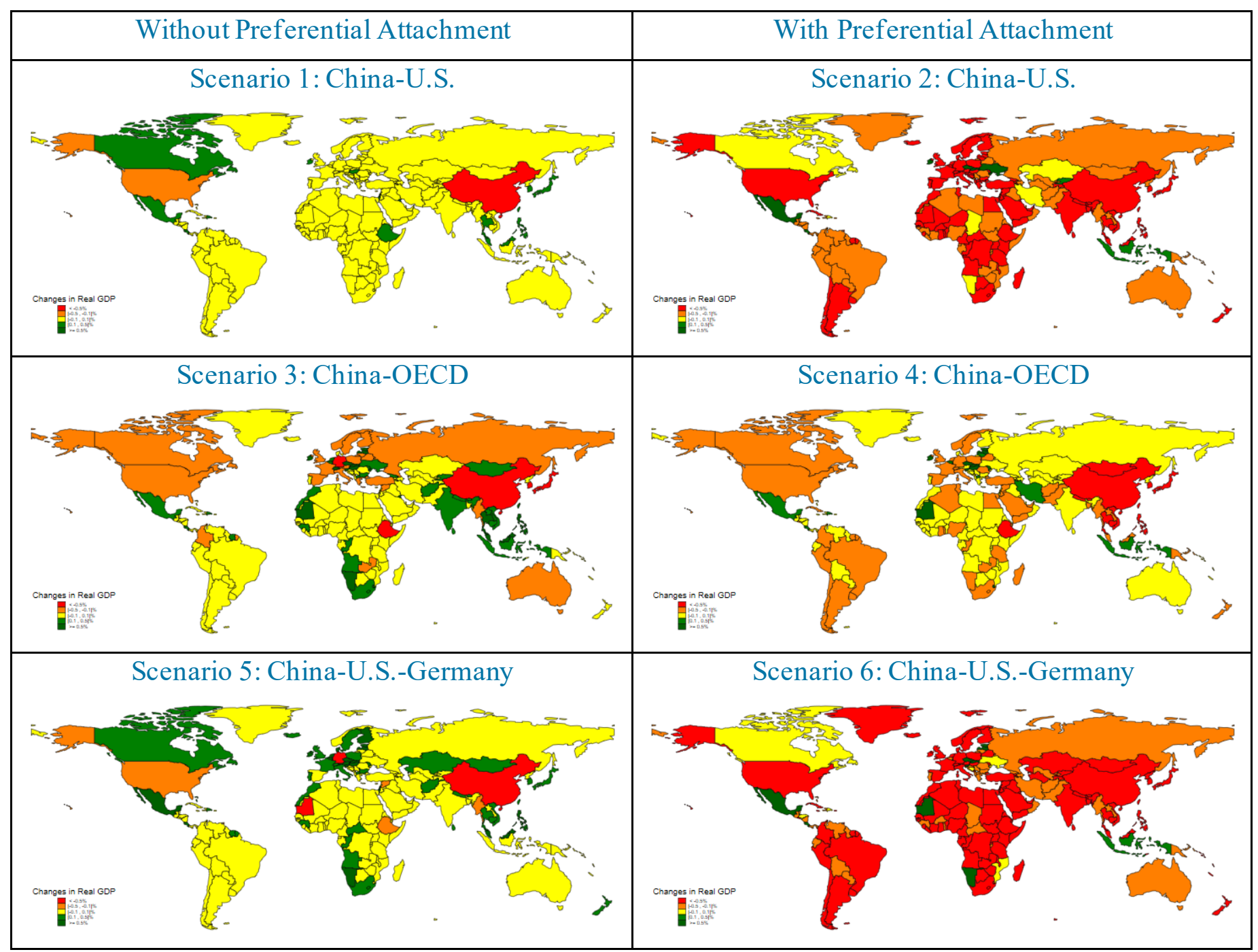

Source: Authors' calculations

\section{c. Lower Foreign Knowledge Diffusion}

In addition to the reduction in global trade flows and sectoral misallocation from technological decoupling, there are potential consequences for innovation and productivity growth. To gauge 
what is at stake, this section provides an empirical estimate of the positive knowledge spillovers among technological leaders since the early 2000s. These estimates will then form the basis of the integrated scenario analysis featuring all three channels in Part III of the paper.

The approach, based on the work by Eugster and others (2018), relies on a two-step estimation and a three-dimensional panel to study the contribution of "accessible" foreign R\&D - the proxy for knowledge available abroad - to domestic innovation and productivity. The findings highlight that knowledge diffusion has made a quantitatively significant contribution to innovation and productivity, including in the United States and China. Even when accounting for the fact that China's R\&D numbers potentially overstate its contribution to global knowledge, it remains among the most important sources of technology spillovers for the United States.

Data. The analysis links productivity and innovation to the available stocks of knowledge both at home and abroad at the country-industry level. As a proxy for productivity, the analysis relies on the productivity of labor, constructed as the ratio of real value added and total employment, both sourced from the KLEMS database. A priori, it would have been preferable to disaggregate labor productivity further into the parts that respectively arise from capital deepening and greater efficiency in the use of the factors of production (total factor productivity, TFP). However, the sectoral data on capital stocks is lacking for China and other countries, which prevents an equivalent analysis of TFP. While this is conceptually unfortunate, it hardly reduces the relevance of the results, as the more easily measured labor productivity - which at the aggregate level is equivalent to GDP per capita - is a standard metric for the production and prosperity of a country.

As a proxy for innovation - the second dependent variable - the number of patent families that can be considered "international" is used. A patent family groups the patent applications (often in different countries) which are associated to each other and relate to the same technology. Specifically, a patent family is treated as "international" if it comprises applications to at least two distinct patent offices. Given that patent applications in another country add an extra layer of costs and complication, this condition is expected to filter applications with limited commercial 
value. ${ }^{8}$ The international patent family is associated with the most frequent country of residence of the first inventor and the year in which the first application was made. ${ }^{9}$ The information on individual patent applications is taken from the PATSTAT database, which is produced and administered by the European Patent Office.

To proxy for the available knowledge, the main variable of interest is constructed based on the discounted sum of R\&D spending in constant PPP U.S. dollars provided by the OECD's ANBERD database. ${ }^{10}$ As further explained below, the raw data interacts with a measure of "accessibility", which is constructed based on patent citations and proxies the share of innovation in a foreign country that is available for use in the home country.

Methodology. Methodologically, this section relies heavily on the empirical framework proposed by Peri (2005) and extended by Eugster and others (2018). The latter estimated knowledge spillovers from the Top 5 innovating countries (France, Germany, Japan, United Kingdom, and the United States) on innovation and productivity among so-called "followers." While remaining close in terms of methodology, the focus is shifted from the spillovers from leaders to followers to the ones among technological leaders.

Using the subscripts $c, i$, and $t$ respectively for country, industry and year, the following model is estimated:

$$
\ln \left(P_{i, c, t}\right)=D_{c, t}+\gamma \ln R_{i, c, t}^{H}+\mu \ln R_{i, c, t}^{F}+\varepsilon_{i, c, t}
$$

In the equation above, $\ln \left(P_{i, c, t}\right)$ stands for the natural logarithm of labor productivity or patenting, $D_{c, t}$ are country time fixed effects and $R_{i, c, t}^{H}$ and $R_{i, c, t}^{F}$ are respectively the discounted

\footnotetext{
${ }^{8}$ Relative to counting only "triadic" patent families, a nother popular measure that only counts innovations with application in each of the patent offices of Europe (EPO), Japan (JPO) and the United States (USPTO), the "international" patent count is less bia sed toward the more tra ditional innovating countries and is thus preferred. For example, procedural and la nguage requirements in Ja pan may provide a bigger deterrent for foreign inventors than these would for Japanese inventors who wish to patent abroad.

${ }^{9}$ A patent application can list several inventors, and the order in which they a re listed is understood to reflect the degree of the contribution. A fractional a ttribution of each patent family to the countries of residence of the different inventors of each individual application produces very similar series.

${ }^{10}$ The construction of the $R \& D$ stock is ba sed on a perpetual inventory method and a discount rate of 10 percenta year, which implies a half-life of newly created information of slightly more than six years.
} 
stock of $\mathrm{R} \& \mathrm{D}$ expenditures up to time $t$ at home and abroad. The foreign $\mathrm{R} \& \mathrm{D}$ stock $R_{i, c, t}^{F}=$ $\sum_{L \neq c} \varphi_{i, c, l} R_{i, l, t}^{H}$ is the weighted sum of the accessible R\&D stocks of key innovating countries, where the weights $\varphi_{i, c, l}$ stand for the fraction of knowledge generated in each technological leader $l$ that is accessible to the home country $c$. These weights are proxied by the predicted value from a gravity regression of bilateral patent citations on geographical, linguistic, and technological distances. ${ }^{11}$

The estimated coefficients from equation (1) are used to approximate the contributions of spillovers from the individual technological leaders $l$ as follows:

$$
\operatorname{contr}\left(\frac{\Delta P_{c, l}^{2000-13}}{P_{c, l}^{2000}}\right)=\mu * \varphi_{c, l} \frac{\Delta R_{i, l}^{2000-13}}{\sum_{l \neq i} R_{i, l}^{2000}}
$$

The contribution of each leader country $l$ to the innovation- or productivity growth in country $c$ is proportional to the change in country l's $\mathrm{R} \& \mathrm{D} \operatorname{stock}\left(\Delta R_{i, l}^{2000-13}\right)$ that is accessible to country $c\left(\varphi_{c, l}\right)$, scaled by the total accessible R\&D stock over all technological leader $\left(\sum_{l \neq i} R_{i, l}^{2000}\right)$. Reflecting the increased importance of China and Korea in global R\&D activities and to investigate the knowledge spillover between China and other technological leaders, this group of "leaders" is extended from the initial Top 5 used by Eugster and others (2018) to include both. ${ }^{12}$ Figures 5 and 6 respectively show the dynamics of R\&D expenditure and innovation in China and Korea and illustrate the importance of using patent families to gauge the latter in a crosscountry setting. In the case of China, the number of patent families with applications in at least two countries significantly lags behind annual R\&D expenditure, which in constant PPP terms has grown to a level second only to the United States.

\footnotetext{
${ }^{11}$ The key a dvantage of using predicted citations as a weight ra ther than actual ones is that it cuts the channel of reversed causality. If more innovation lea ds to more citations, using those as a weight would increase the accessible foreign R\&D and attribute a positive effect that could be completely spurious. In addition, thepredicted values can ea sily be purged of patenting and citation culture by excluding country-time and industry fixed effects. See Appendix III and Eugster and others (2018) for more details on the first stage estimation.

${ }^{12}$ Given more limited a vailability of sectoral R\&D data, the inclusion of China in the group of technological lea ders curtails the estimation sample to start in the year 2000 rather than 1995. In addition, no information is a vailable for neither the wood and paper nor the rubber and plastic sectors.
} 
Figure 5. Gross R\&D Expenditure

(Domestic, US\$ millions, constant PPP)

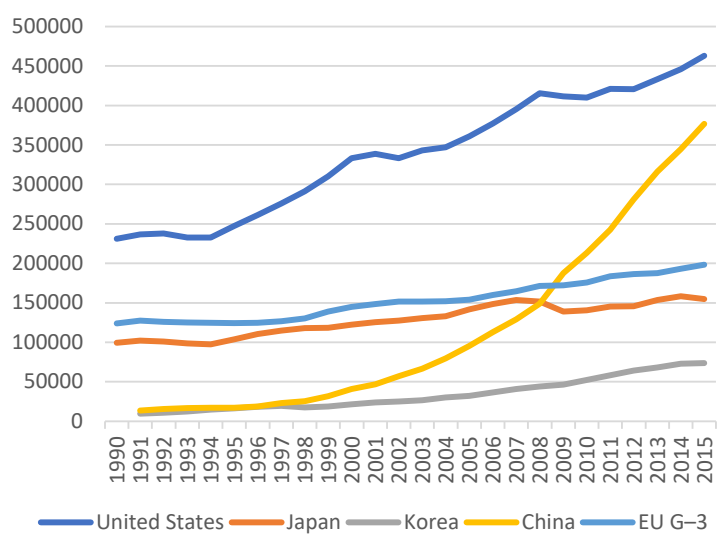

Figure 6. Patenting

(International patent families by publication year)

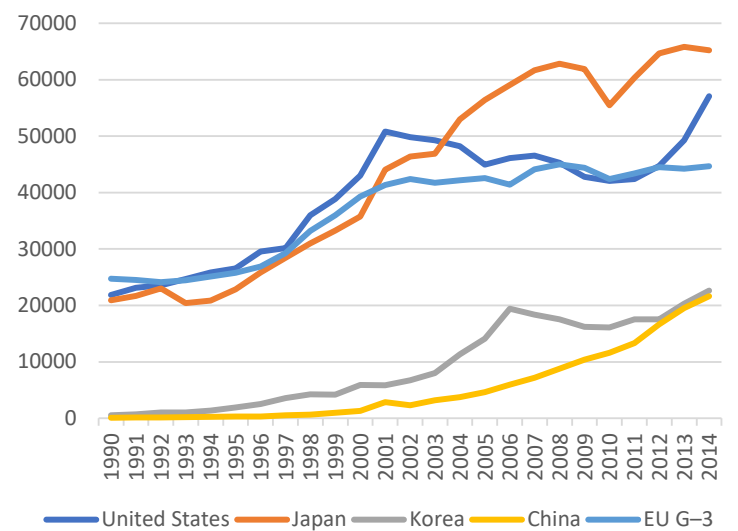

Note: EU-G3 reflects the sum of R\&D spending in France, Germany, and GreatBritain.

Source: OECD ANBERD.

The discrepancy between the two series raises the concern that Chinese R\&D numbers may overstate the country's contribution to the technological frontier. In this analysis, overstating China's share in the foreign $\mathrm{R} \& \mathrm{D} R_{i, c, t}^{F}$ of its partner countries would also overstate its contribution to their innovation and productivity growth. ${ }^{13}$ As will be shown below, if left unadjusted, the R\&D would imply implausibly-high effects from China’s R\&D.

To address this issue, adjusted R\&D numbers are constructed for China (see Appendix III). The preferred adjustment involves a rescaling of the research input with an estimate of its research output. Its rationale is very simple: the ability of the stock of $R \& D$ expenses to proxy for the available knowledge relies on the assumption that money is transformed into ideas at a reasonably comparable rate. Given that this may not be the case for China, the research input is rescaled by an approximate estimate of this rate of transformation in the other countries; their "research productivity".

Results. Figure 7 illustrates the magnitude of knowledge spillovers among technological leaders to their annual labor productivity growth, as laid out in equation 2. Four points stand out: First,

${ }^{13}$ Expanding $\frac{\Delta R_{i, l}^{200-13}}{\sum_{l \neq i} R_{i, l}^{200}}$ in equation (2) to $\frac{\Delta R_{i, l}^{2000-13}}{R_{i, l}^{2000}} * \frac{R_{i, l}^{2000}}{\sum_{l \neq i} R_{i, l}^{2000}}$ illustrates that the contribution is a gain proportional to the growth rate of the foreign country's R\&D stock a nd its share among technological lea der. 
for all countries the estimated contribution to annual labor productivity growth between 2000 and 2013 from foreign R\&D is quantitatively significant; approximately $0.4-0.5$ percent. This is particularly striking when the contribution is compared to the often-disappointing productivity growth observed in reality. Second, for China, as well as others, the United States and (to a lesser extent) Japan are the biggest sources of knowledge spillovers. Third, for other countries the contribution from China has been sizeable and bigger than the ones from the traditional technological leaders from Europe, even when using conservative estimates of Chinese R\&D expenses. Finally, based on the analysis of patent citations, all countries appear to have increasingly benefited from China's innovation drive, including the United States.

\section{Figure 7. Productivity Spillovers Over Time}

(average implied contribution per year, in percent of GDP)

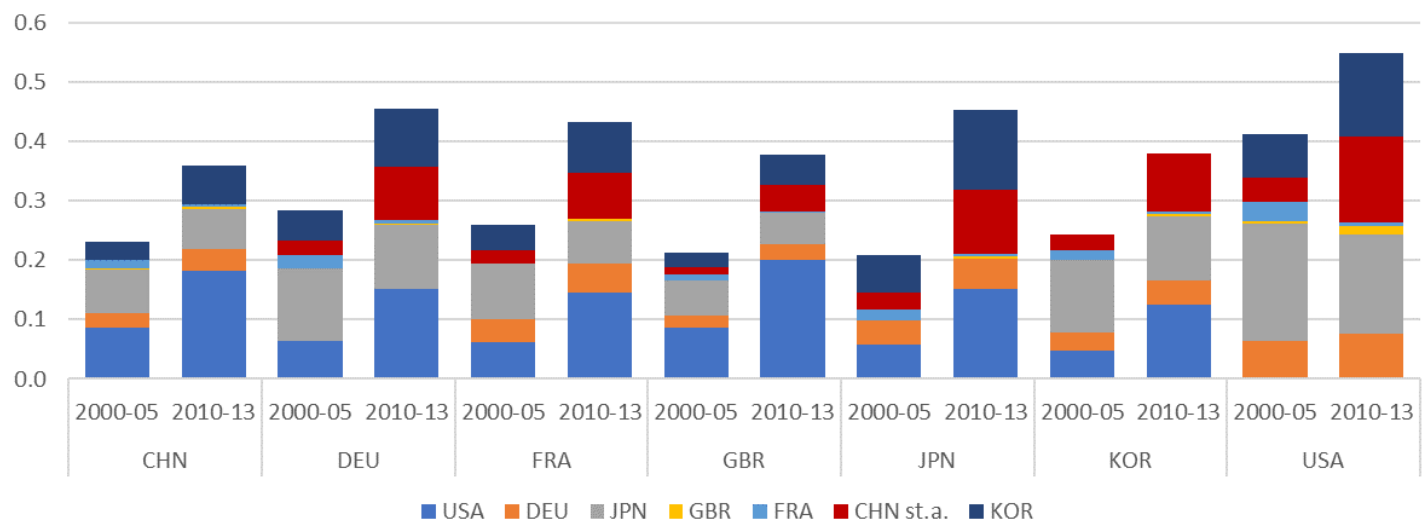

Note: The figure shows the implied contribution from the knowledge spillovers of the different technological leaders to the annual la bor productivity growth in the country on thex-axis. Chinese $R \& D$ numbers are resca led to match the a verage patenting productivity using the discounted stock as reference.

Sources: OECD ANBERD and a uthors' calculations

\section{Adding It All Up in a Global Dynamic Macroeconomic Model}

The three channels of technological decoupling considered above are combined in GIMF to determine the aggregate impacts on the major global regions. With the direct impact on trade volumes in high-tech goods already modelled in GIMF, this requires incorporating the CFRT results for sectoral misallocation and the estimates of patent and R\&D linkages to productivity. 
Sectoral misallocation cannot be represented directly in GIMF which only features a tradable and nontradable sector for each country. Instead the disaggregated sectoral changes in labor productivity computed from CFRT are aggregated for the tradable and nontradable sectors and applied directly in GIMF. This permanent decline in the level of productivity is assumed to happen relatively quickly over 3 years.

Similarly, as the links between regions' labor productivities related to $R \& D$ and patents are not directly modelled in GIMF, the estimates on lower knowledge diffusion are included as an additional slowdown in GIMF's labor productivity growth for tradables. Spillovers between the relevant hubs (and all countries in the preferential attachment scenarios) are assumed to be zero, reducing productivity growth by the amount illustrated in Figure 7 over the 2010-13 period, for eight years. Afterwards, it is assumed that labor productivity growth returns to its previous rate over 3 years, as global conditions stabilize as the different blocs of countries normalize their technology-sharing relationships. However, the cumulative losses from growth over the 11 -year horizon are permanent on level of labor productivity and hence real GDP.

\section{a. Overview of the Results}

Figure 8 presents results for the six technological decoupling scenarios outlined in Table 1. China usually loses the most in each scenario reflecting very large effects through the trade and sectoral-misallocation channels. Generally, some countries can gain in the scenarios without preferential attachment, as those countries act as partial substitutes for a hub-for example, India can help replace China for the United States or Germany on the margin in Scenarios 1, 3 and 5. Scenarios 3 and 4 lead to the largest losses for China, as it breaks up two pairs (China and Japan; China and Korea) that are present in the other four scenarios, and are most beneficial to China, Japan and Korea. Other regions outside of Asia lose the most under Scenario 6, as regions would no longer trade with two major hubs instead of just one. 
Figure 8. Technological Decoupling Scenarios: Real GDP for Selected Regions (Percent deviation from the IMF's October 2020 WEO)

Scenario 1: China-U.S. w/o preferential attachment
Scenario 3: China-OECD w/o preferential attachment
Scenario 5: China-U.S.-Germany w/o preferential attachment

China

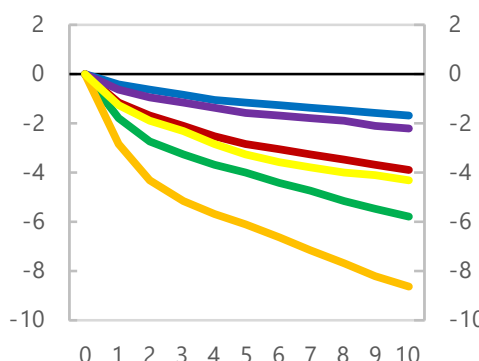

Years

India

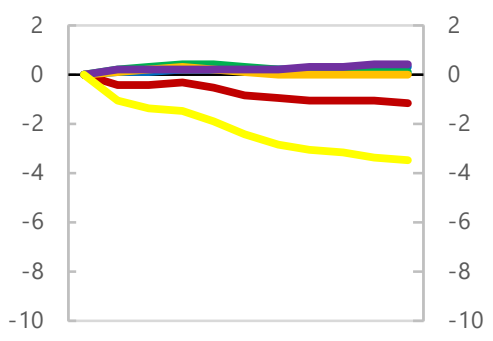

$\begin{array}{llllllllllll}0 & 1 & 2 & 3 & 4 & 5 & 6 & 7 & 8 & 9 & 10\end{array}$

Years
United States

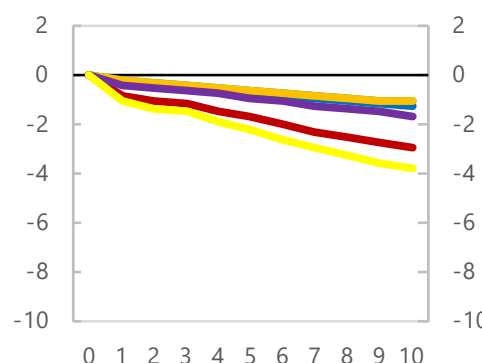

Years

Japan

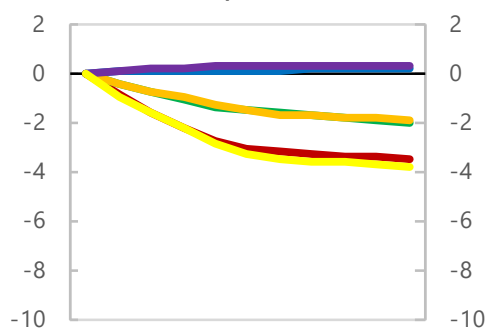

$\begin{array}{lllllllllll}0 & 1 & 2 & 3 & 4 & 5 & 6 & 7 & 8 & 9 & 10\end{array}$

Years
-Scenario 2: China-U.S. with preferential attachment

- Scenario 4: China-OECD with preferential attachment Scenario 6: China-U.S.-Germany with preferential attachment

Source: Authors' calculations.

\section{b. Contributions of the Three Channels and Their Regional Impacts}

To understand how the three components of decoupling affect the aggregate results, it is useful to drill down for some of the regions using the example of the China-United States decoupling scenario, without and with preferential attachment (Figure 9). The first layer (the dotted lines) shows the impact of the collapse in high-tech goods trade. The second layer (the dashed lines), adding the costs due to misallocation of labor and capital across sectors (based on Table 3), significantly amplifies the costs. The third layer (the solid lines), assuming temporary reductions in labor productivity growth in tradable goods sectors due to lower knowledge diffusion (based on Figure 7), has a significant impact particularly for the United States, and a notable, but more modest, impact elsewhere. 
Figure 9. China-U.S. Technological Decoupling Scenarios: Real GDP for Selected Countries

(Percent deviation from the IMF's October 2020 WEO)

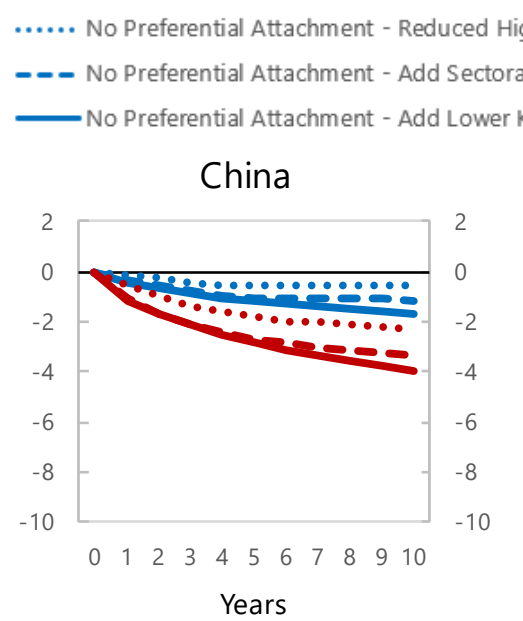

Source: Authors' calculations.
...... Preferential Attachment - Reduced High-Tech Trade Shock

- - Preferential Attachment - Add Sectoral Misallocation Shock

_ Preferential Attachment - Add Lower Knowledge Diffusion Shock
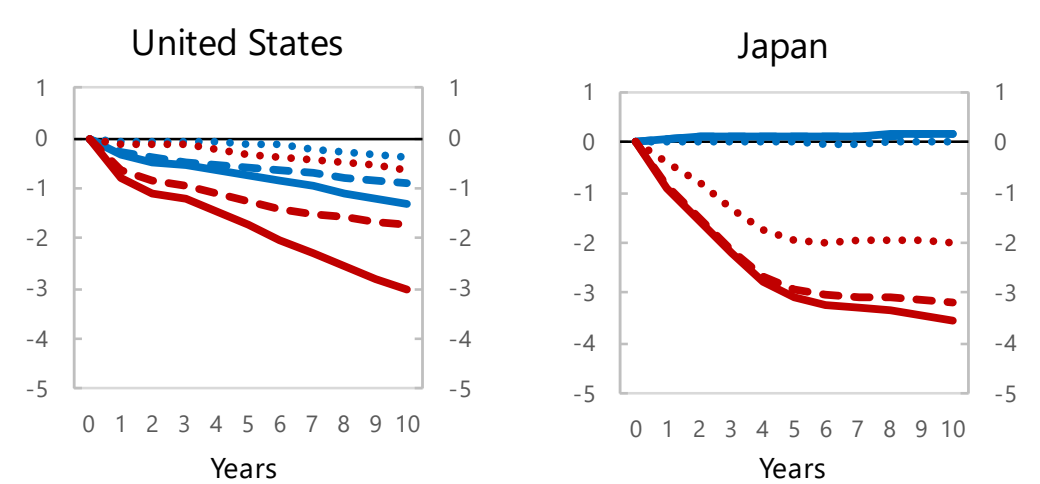

There are large impacts on both China and the United States, though the impact would be relatively larger on China, given its strong connections with the United States through all three components - trade, sectoral misallocation and knowledge diffusion. The United States loses almost as much through knowledge diffusion as China when only China and the United States decouple. The United States will lose more through knowledge diffusion than China when there more countries decouple from the United States because of preferential attachments with China.

Non-hub countries, such as Japan (Figure 9, right-most panel), face different impacts if decoupling also leads to preferential attachment. If only China and the United States stop trading, Japan marginally gains from trade diversion. However, Japan will lose with preferential attachment to China because it breaks its strong links to the United States, especially through the trade and sectoral misallocation channels.

\section{c. The Economic Mechanisms in Detail}

What are the underlying economic mechanisms driving the aggregate real GDP effects discussed so far? Consider the case of the United States under Scenario 2, when China and the United States decouple with preferential attachments (Figure 10). 
Figure 10. The Impact of Scenario 2 (China-U.S. Technological Decoupling with Preferential Attachment) on the United States

(Percent deviation from the IMF's October 2020 WEO)

Reduced High-Tech Trade Shock

Real GDP

(Percent Difference)

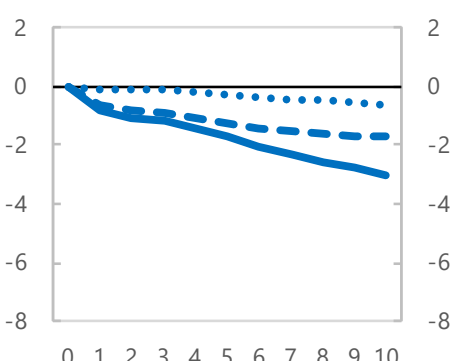

Years

Current Account (Percent of GDP Difference)

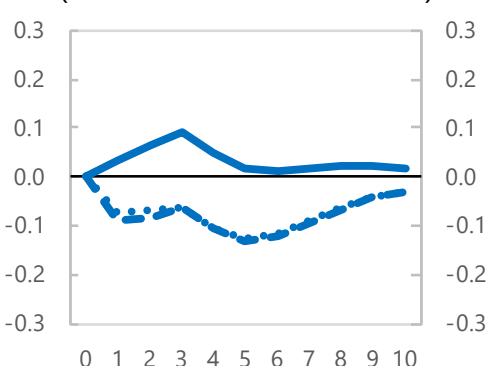

Years

Price of Investment (Percent Difference)

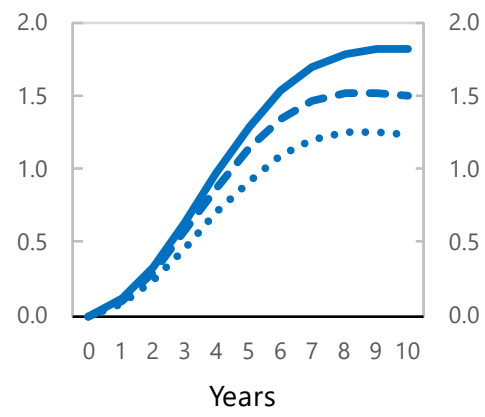

Source: Authors' calculations.
Add Sectoral Misallocation Shock Consumption (Percent Difference)

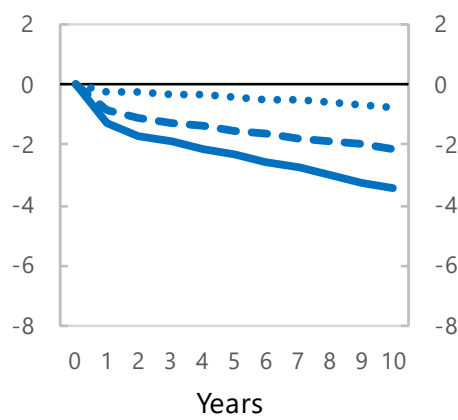

Real Exports (Percent Difference)

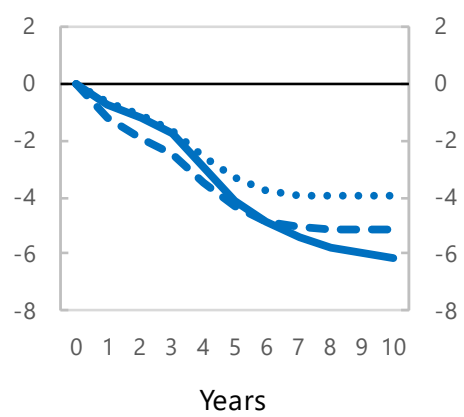

Real Eff. Exchange Rate (Percent Difference)

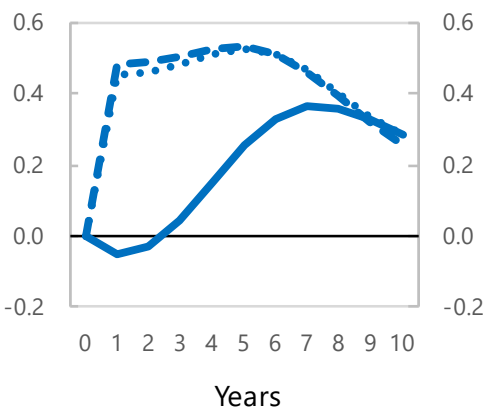
Add Lower Knowledge Diffusion Shock

Investment (Percent Difference)

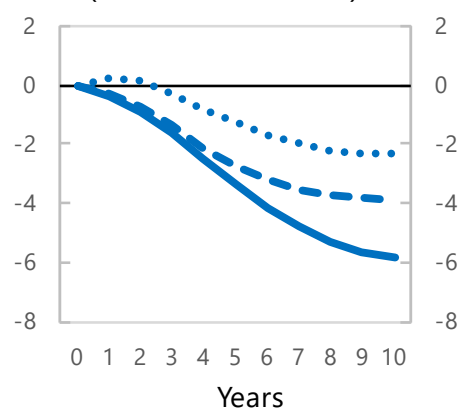

Real Imports (Percent Difference)

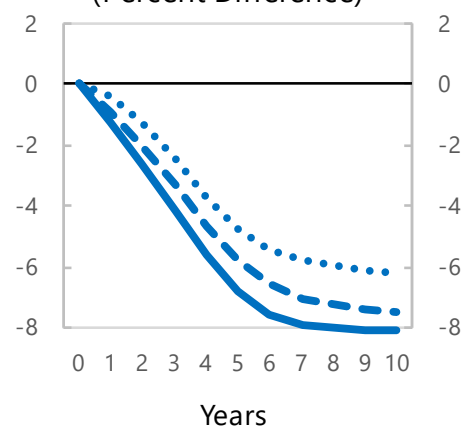

Real Interest Rate (Percentage Point Difference)

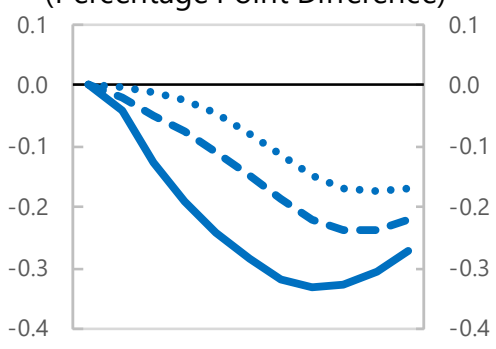

$\begin{array}{lllllllllll}0 & 1 & 2 & 3 & 4 & 5 & 6 & 7 & 8 & 9 & 10\end{array}$ Years

The layer related to reduced global trade flows (dotted lines) has its strongest impacts on export and import volumes, and leads to an appreciation of the real effective exchange rate (REER), 
meaning there is only a slight adjustment in the current account position. The fall in imports sees a substitution to domestic production, which helps also minimize the impact from lower exports. Therefore, real GDP falls by a limited amount, also reflected in consumption. Because the United States curtails its imports of high-tech goods, the price of investment increases, even with substitution towards U.S. high-tech goods.

The layer illustrating the decline in productivity because of sectoral misallocation (the gap between the dotted and dashed lines) reduces U.S. productive capacity which increases the relative price of investment further, discouraging investment and causing a fall in wealth and therefore consumption. Export demand falls since U.S. goods are more expensive abroad, while import demand falls in line with consumption and investment. The impact is about as large on real GDP as the trade layer.

Finally, the layer illustrating lower knowledge diffusion (the gap between the dashed and solid lines) behaves much like that of sectoral misallocation, but is of a greater magnitude. Moreover, the impacts accumulate more slowly, as the shock on the level of productivity builds over a longer time period than that of sectoral misallocation. The one key difference is the behavior of the REER, where the decrease in tradables relative to non-tradables productivity leads to a Balassa-Samuelson effect, depreciating the REER.

While the scenarios abstract from structural or industrial policies, they account for the (endogenous) reaction of macroeconomic policies. Monetary policy - which is assumed to follows an interest rate reaction function based on the deviation of inflation from its target - is offsetting some of the short-term effects of the shocks affecting the economies involved, as inflation contracts in line with economic activity and due to the appreciation of the REER. This is despite inflationary pressures associated with the declines in labor productivity in two of the layers. Fiscal policy - an automatic stabilizer where transfers to households increase as the output gap (the deviation of real GDP from its potential path) goes into excess supply - plays only a small role in mitigating the short-term negative impacts. The underlying shocks are 
supply-side ones, so potential output falls almost as fast as output and the output gap does not move much from its baseline.

Each region experiences similar impacts qualitatively to the United States for each of the three layers, but the magnitudes differ. Magnitudes are smaller for non-hub countries in the scenarios without preferential attachment. In all scenarios, more open economies (especially those with smaller shares in the global economy) experience larger negative impacts, especially since monetary policy cannot be as effective because of leakages through trade flows.

\section{Concluding Remarks}

This paper provides a framework to think about (1) possible ways in which global trade in hightech sectors could fragment, and (2) the different channels through which this fragmentation can affect the global economy. Several hypothetical, stylized alternatives of such technological decoupling were considered, with different technology hubs and varying roles for non-hub countries. The channels considered account for reduction in global trade volumes, sectoral misallocation effects, and lower international knowledge diffusion. All the channels are explicitly modeled and then embedded in a dynamic macroeconomic model.

Decoupling is typically very costly for the main technology hubs involved and for most countries across the world, in particular China, followed closely by major hubs like the United States or Germany (selected to represent an European technology hub). Non-hub countries sometimes gain in scenarios without preferential attachment (i.e. where non-hub countries continue to trade freely with all technology hubs), as they can act as partial substitutes for a hub-for example, India can help replace China for the United States or Germany. Overall, however, most countries lose, and losses scale up with the degree of fragmentation. Multipolar worlds where non-hub countries are expected to trade with a single technology hub are especially harmful.

Future work should try to shed light on those channels that are not accounted for in the present paper. This would include the potential effects from changes in foreign investment policies, to 
trade in services, and to industrial policies aimed at mitigating the productivity impact of the loss of access to foreign technologies. 


\section{Appendix I. Data Sources for CFRT}

The original Eora database represents a balanced global MRIO table linking 26 sectors across 190 countries, with a complete annual time-series over the period 1990-2015. See Lenzen and others (2013) for a detailed description of the Eora database. The model's trade-flow data correspond to the latest (2015) Eora table. For the analysis presented in this paper, the Eora database is combined with 2015 applied tariff data from UNCTAD's Trade Analysis Information System accessed through WITS. The intersection of both databases results in a combined inputoutput database, with 17 sectors and 165 countries. Appendix Table I.1 shows the sectors considered in the calibration.

Appendix Table I.1: Sectors Considered in the Analysis

\begin{tabular}{ll}
\hline Goods & Services \\
Agriculture & Construction \\
Extractive industries & Wholesale \& retail \\
Food & Hotels \& restaurants \\
Textile & Transport \& communication \\
Wood \& paper & Financial services \\
Chemicals \& oil derivatives & Other services \\
Metals & \\
Electronics & \\
Transport goods & \\
Other manufacturing & \\
Electricity & \\
\hline
\end{tabular}

Source: Caceres and others (2019). 


\section{Appendix II. The IMF's Global Integrated Monetary and Fiscal model (GIMF)}

\section{a. Summary of New Features in the Theoretical Model}

The IMF's Global Integrated Monetary and Fiscal model (GIMF) is an annual, multi-region, micro-founded general equilibrium model of the global economy. The core model is documented in Kumhof and others (2010) and Anderson and others (2013).

This version of the model has more detail in trade overall. Unlike in the standard GIMF, imports of consumption and investment goods are always treated separately, and not just as a single imported final good. Non-tariff barriers (NTBs) are also present, where country A imposes the NTB, but country B will bear the cost in its production processes, and then have to pass it back to the importing consumers through higher prices. This is unlike tariffs, which would be imposed by country A on country B, and country A's government then collects the tariff revenues which it can then redistribute; Country B facing the tariff only experiences shifts in demand from the importing consumers in Country A who bear the cost of the tariff.

High-tech goods are not broken out separately in GIMF but can be identified in the data used to calibrate the model, so high-tech goods are primarily part of investment and intermediate goods.

The services sector is a special feature of this application of GIMF and is not documented in the two aforementioned papers. Services (including travel, transport, logistics, financial services, etc.) are produced in the same manner as consumption and investment goods from a combination of tradable and nontradable goods, along with a term for productivity. Services can be consumed by domestic households or by foreigners, in which case it registers as exports for the region and as imported services for the foreigners' region. Consequently, households have a two-item consumption bundle made up of services and consumption goods. The services portion consists of domestic services produced, and imports from foreign markets. As with consumption goods, based on its production and consumption structure, services have a price, and forms part of the consumption basket, thereby having a role in determining consumer price (CPI) inflation. Trade 
in services is tracked bilaterally between all regions, just like consumption, investment and intermediate goods.

\section{b. Summary of the Model Calibration}

An eight-region version of GIMF is used, focused on Asia-Pacific regions - China, the United States, the euro area, India, Japan, Korea, the other Asia-Pacific countries, and a remaining countries bloc.

\begin{tabular}{|c|c|c|c|c|c|c|c|c|}
\hline \multicolumn{9}{|c|}{$\begin{array}{c}\text { Appendix Table II.1: Key National Accounts Ratios in GIMF } \\
\text { (Percent of a region's GDP, unless otherwise stated) }\end{array}$} \\
\hline & & United & & & & & Other Asia & Remaining \\
\hline & China & States & Europe & India & Japan & Korea & Pacific & Countries \\
\hline Share of Global GDP (\%, US\$) & 15.74 & 24.23 & 16.06 & 3.20 & 5.85 & 2.03 & 5.77 & 24.23 \\
\hline \multicolumn{9}{|l|}{ Domestic Demand } \\
\hline Household Consumption & 47.5 & 65.2 & 58.6 & 60.1 & 55.2 & 54.7 & 61.1 & 58.5 \\
\hline Private Investment & 27.5 & 17.4 & 23.1 & 17.0 & 25.5 & 19.3 & 18.5 & 23.5 \\
\hline Government Absorption & 25.0 & 17.4 & 20.3 & 11.0 & 20.5 & 15.0 & 13.4 & 20.0 \\
\hline \multicolumn{9}{|l|}{ Trade } \\
\hline Goods Exports & 17.7 & 9.1 & 17.5 & 13.5 & 14.5 & 34.7 & 35.5 & 20.6 \\
\hline Consumption & 8.2 & 4.1 & 8.2 & 6.3 & 5.4 & 7.4 & 13.7 & 5.8 \\
\hline Investment & 4.6 & 1.5 & 4.3 & 1.9 & 4.1 & 8.3 & 6.0 & 2.9 \\
\hline Intermediate & 4.9 & 3.5 & 5.0 & 5.3 & 5.0 & 19.0 & 15.8 & 11.9 \\
\hline Service Exports & 1.8 & 4.7 & 7.4 & 8.3 & 3.8 & 4.6 & 9.2 & 4.7 \\
\hline Goods Imports & 15.4 & 11.3 & 18.7 & 17.4 & 11.4 & 31.8 & 36.4 & 18.9 \\
\hline Consumption & 3.1 & 5.7 & 8.1 & 3.8 & 5.6 & 8.1 & 11.7 & 8.1 \\
\hline Investment & 2.2 & 2.3 & 3.3 & 2.4 & 1.8 & 5.3 & 8.3 & 4.3 \\
\hline Intermediate & 10.1 & 3.3 & 7.3 & 11.2 & 4.0 & 18.4 & 16.4 & 6.5 \\
\hline Service Imports & 4.0 & 2.5 & 6.2 & 4.3 & 6.9 & 7.6 & 8.2 & 6.4 \\
\hline
\end{tabular}

Structurally, each country/regional block is close to identical, but with different key steady-state ratios and behavioral parameters (Appendix Table II.1). These are drawn from stylized data set consistent with 2018, and assumptions on long-term values for certain stocks, such as the capitalto-output and government debt-to-GDP ratios. There is data also for services, for exports, imports and consumption, from which its production data is derived. All of this data allows for the calibration of the model parameters. 
Many of the elasticities in GIMF are calibrated the same across regions, but each region has a unique set of related bias parameters. The bias parameters, given the elasticities, are computed based on the calibration of key steady-state ratios. This is also true of the bias parameters for trade. Those for goods trade rely on the U.N. COMTRADE database and the IMF's Direction of Trade Statistics. Those for services rely on the U.N. and OECD EBOPS databases.

Behavior is governed by elasticities calibrated with some differences from the goods sectors (Appendix Table II.2). The demand between services and other consumption is relatively inelastic; the demand between services in the region or abroad is also relatively inelastic; but between different foreign markets, it is more elastic. This is in contrast to

\begin{tabular}{|c|c|c|c|}
\hline $\begin{array}{l}\text { Elasticity } \\
\text { between => }\end{array}$ & $\begin{array}{l}\text { Consumption } \\
\text { and Services }\end{array}$ & $\begin{array}{c}\text { Domestic / } \\
\text { Foreign } \\
\text { Services }\end{array}$ & $\begin{array}{l}\text { Foreign } \\
\text { Services }\end{array}$ \\
\hline Services & 0.9 & 0.9 & 1.5 \\
\hline $\begin{array}{l}\text { Elasticity } \\
\text { between => }\end{array}$ & & $\begin{array}{c}\text { Domestic / } \\
\text { Imported } \\
\text { Goods }\end{array}$ & $\begin{array}{c}\text { Different } \\
\text { Regions' } \\
\text { Goods }\end{array}$ \\
\hline Consumption & - & 1.5 & 1.5 \\
\hline Investment & - & 1.5 & 1.5 \\
\hline Intermediates & - & 1.5 & 1.5 \\
\hline
\end{tabular}

Source: Authors' calculations. the trade in consumption, investment and intermediate goods, which is relatively elastic between domestic and foreign goods, with the same higher elasticity among foreign markets.

In the short term, the degree and rapidity with which various sectors of the economy adjust are governed by real rigidities and nominal adjustment costs. Real rigidities play a small role in GIMF's annual dynamics and are set to 1 across all regions for all variables (labor demand, liquidity constrained households, investment, and imports of consumption, investment and intermediate goods and services) except consumption by saving households which is set to 2 . Nominal adjustment costs are set the same across domestic (tradable intermediates, nontradable intermediates, final consumption goods, final investment goods, services), although they are higher in the euro area to reflect greater structural rigidities. However, they vary widely across regions for imports (Appendix Table II.3). Countries which are large import markets (like the United States) have high adjustment costs, meaning exporters can only adjust their prices slowly in those markets. Small open economies (such as the other Asia-Pacific region) are essentially price takers - exporters to these markets can quickly shift their prices. 


\begin{tabular}{|c|c|c|c|c|c|c|c|}
\hline \multicolumn{8}{|c|}{ Appendix Table II.3: Calibration of Nominal Adjustment Costs } \\
\hline & China & $\begin{array}{l}\text { Euro } \\
\text { Area }\end{array}$ & $\begin{array}{l}\text { United } \\
\text { States }\end{array}$ & India & Korea & Japan & $\begin{array}{l}\text { Other } \\
\text { regions }\end{array}$ \\
\hline Real wage & 100 & 150 & 100 & 100 & 100 & 100 & 100 \\
\hline Consumption price & 100 & 150 & 100 & 100 & 100 & 100 & 100 \\
\hline Services price & 100 & 150 & 100 & 100 & 100 & 100 & 100 \\
\hline Investment price & 100 & 150 & 100 & 100 & 100 & 100 & 100 \\
\hline Intermediate prices & 100 & 150 & 100 & 100 & 100 & 100 & 100 \\
\hline \multicolumn{8}{|l|}{ Price of imports of } \\
\hline Goods & 25 & 50 & 100 & 10 & 25 & 33 & 17 \\
\hline Services & 25 & 50 & 100 & 10 & 25 & 33 & 17 \\
\hline
\end{tabular}

\section{c. Summary of Assumptions Underpinning the Use of GIMF}

Readers should keep in mind that the results from the scenarios simulated with GIMF are underpinned by the following assumptions:

1) All agents in the model (including households, firms and the fiscal and monetary authorities) have perfect foresight.

2) All regions in GIMF have the same economic structures, differing only through their parameterization and calibration.

3) The model is at an annual frequency, so degree of detail for some of the economy's dynamics are lost, particularly in the first year for investment.

4) The baseline calibration of GIMF is based on parameter values consistent with 2018 for the great ratios to GDP such the capital stock, government debt and deficit, net foreign assets and current account balance, and national accounts aggregates as well as trade flows and services data.

5) The model has non-linearities in the financial accelerator, and potential for non-linearities in the conduct of monetary policy by either encountering the zero-interest-rate floor or using monetary accommodation (features not used here). Otherwise, the model is approximately linear for small enough shocks. 
6) The real exchange rate is a "jumper," adjusting immediately in the first year to shocks, since it follows the standard forward-looking, risk-adjusted uncovered interest rate parity condition which equates the forward sum of national-U.S. interest rate differentials with the one-year-forward difference in the nominal exchange rate. However, there is no financial friction in the equation required to bring the net foreign asset position to its steady state, as the net foreign asset position and its dynamics solve endogenously as part of the OLG framework.

7) There are no substantial financial market channels. GIMF only has a financial accelerator (albeit using the full general equilibrium form with non-linearities) and assumes complete domestic ownership of firms. All net foreign asset positions are denominated in U.S. dollars, in all countries.

8) Monetary and fiscal policy in this paper's scenarios are passive, relying only their standard policy rules for inflation targeting and debt-to-GDP targeting (with automatic stabilizers) respectively. 


\section{Appendix III. Knowledge Diffusion: Methodological Details and Estimation Results}

\section{a. Methodological Details}

As discussed in the main text, Chinese patenting productivity is by assumption equal to the average of the other countries and, taking patenting (the numerator) as given, the R\&D spending is adjusted (the denominator) accordingly. China's "adjusted" stock of R\&D spending is thus the product of its patenting measure and the research productivity of the other six top innovating countries.

$$
R \& D_{C H N, i, t}^{a d j}=P A T_{C H N, i, t} * \sum_{l \neq C H N} \frac{P A T_{l, i, t}}{R \& D_{C H N, i, t}}
$$

In the above equation, $P A T_{C H N, i, t}$ and $P A T_{l, i, t}$ can either refer to the stock or the annual flow of patenting. Using the more slow-moving discounted cumulative sums both for the R\&D spending and patenting produces reasonably stable relationships. The resulting adjustment is also more conservative than, for example, one relying on the productivity of the patenting flow. ${ }^{14}$ The latter leads to simulated R\&D numbers that are slightly higher than the ones from the stock-adjustment, as well as qualitatively similar but slightly higher spillovers from China. Both adjustments produce R\&D stocks for China that are close to the ones of France, the United Kingdom and Korea in the mid-2010s, but below the ones of Germany, Japan and the United States (see Appendix Figure III.1).

\footnotetext{
${ }^{14}$ The very dynamic evolution of patenting in China has led to a flow measure that compares more favorably to its peers than its pa tenting stock (which puts a bigger weight on the research output of the past). Using the flow of patenting ra ther than the stock thus increases $P A T_{C H N, i, t}$ by more than $\sum_{l \neq C H N} P A T_{l, i, t}$.
}

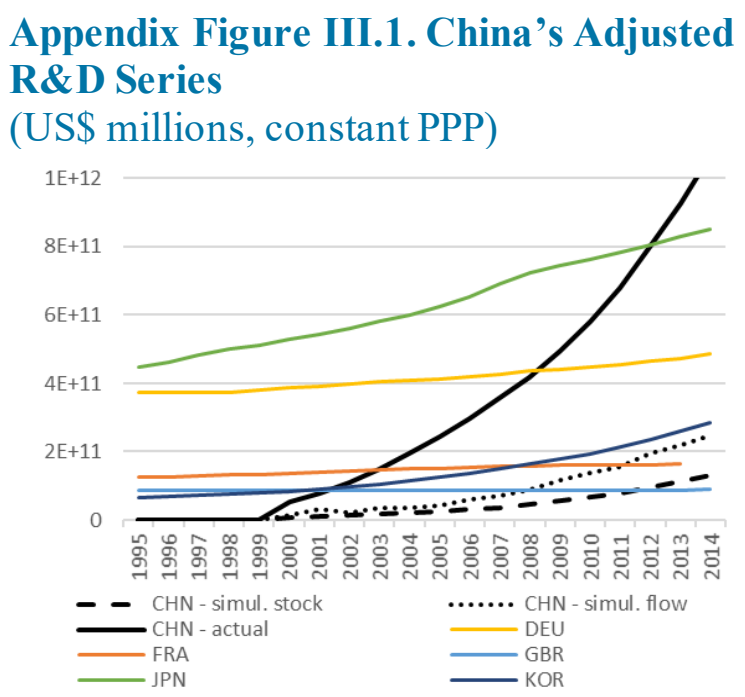

Note: The figure compares the actualand a djusted R\&D expenses in China with those reported by other countries.

Sources: OECD ANBERD and a uthors' calculations 
While the adjustment is an approximation, the procedure produces realistic "guesstimate" of the benefits of Chinese innovation to other technological leaders. In fact, using international patent families may even result in an overly cautious estimate. This could be the case, for example, if international patent families underestimate the rate of China's innovation. This is plausible as the degree of deterrence of the additional cost and complication related to patenting abroad likely depends - among other things - on procedural differences (e.g. language), the size of the domestic market and the economic integration with other countries. These are all factors, which would suggest that a patent productivity of European countries - when measured in international patents - might be a relatively high bar for China. ${ }^{15}$

\section{b. Results}

This section presents the estimated coefficients of domestic and foreign R\&D - respectively $\gamma$ and $\mu$ in equation (1) - as well as the implied magnitude of the productivity and knowledge spillovers from the individual countries. ${ }^{16}$ The results highlight that the foreign knowledge is a significant and quantitatively important driver of domestic innovation and productivity, including for the United States and China.

Appendix Table III.1 shows the effects of domestic and foreign R\&D on patenting. The different columns use different sets of countries for the source and recipient countries of knowledge spillovers. Column (1) shows the spillovers from the Top 7 leaders to all other countries, column (2) and (3) the ones among technological leaders, respectively excluding or including China and Korea. Columns (4) and (5) differ from column (3) as they use R\&D data for China that are adjusted to the patenting productivity, measured either in terms of the discounted stock or the flow of international patents.

\footnotetext{
${ }^{15}$ The da ta indeed supports the idea that incentives for obtaining patents internationally differ a cross countries. While the low share of Chinese patent families that can be considered international is likely rela ted to patenting promotion policies depressing the a verage quality, similar differences can be observed a mong other countries. The respective shares a re higher in the individually smaller buthighly integrated European countries than in the often larger and less integrated countries such as the United States, Ja pan, and Korea.

${ }^{16}$ As the results of the gravity model of patent citations - used for the calculation of the "accessibility" proxy - are not central to the messages of the paper and differ only marginally from the ones reported in Eugster and others (2018), they are reported and discussed in Appendix IV.
} 
Appendix Table III.1: Patenting as a Function of Domestic and Foreign R\&D

(1)

\begin{tabular}{lcc} 
& Followers & Top \\
Foreign R\&D & $0.299 * * *$ & 0.516 \\
& $(5.89)$ & $(2.60)$ \\
Domestic R\&D & $0.468 * * *$ & 0.337 \\
& $(8.48)$ & $(1.6$ \\
\hline Country-Year FE & Yes & Yes \\
$\mathrm{N}$ & 3117 & 950 \\
$\mathrm{R} 2$ & 0.777 & 0.745
\end{tabular}

(2)

Top 5

(2.60)

0.337

(1.66)

950
(3)

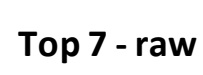

0.549**

(2.43)

0.309

(1.37)
(4)

Top 7 - stock adjusted

$0.497^{* *}$

(2.12)

0.332

(1.32)
(5)

Top 7 - flow adjusted

$0.483^{* *}$

(2.09)

0.350

(1.42)

Note: The table shows coefficients and t-statistics of a panel regression with country-year fixed effects. All regressions exclude the coke and petroleum sector. Top 7 regressions additionally exclude the wood and plastic sectors given missing da ta for China. Followers in column (1) are all countries excluding the Top 7. Variables a re in natural logarithms. Standard errors are clustered at the country-industry level. $* p<0.10, * * p<0.05, * * * p<0.01$ Source: Authors' calculations.

The coefficient on foreign $R \& D$ is substantially smaller for followers (in column 1) than among technological leaders (column 2 to 5 ). This is consistent with other analyses at the sectoral level. (IMF 2018a), as well as findings from micro data (e.g. Chen and Dauchy, 2018). How exactly technological leaders are defined, and whether the Chinese R\&D numbers are rescaled, is of second-order importance. The coefficients on foreign as well as domestic R\&D is quite similar across the columns (2) to (5). This is reassuring, but not very surprising. Notably, the use of country-time fixed effects means that the identification of the effect relies on the relative differences across sectors and time. A proportional increase across all sectors would slightly increase the weight of the affected country (given the bigger residuals) but not otherwise alter the coefficient. It is also noteworthy that among technological leaders, the coefficient on foreign R\&D seems to be larger in magnitude and more precisely estimated than the one on domestic R\&D. According to the coefficients, domestic innovation would increase by 50 percent if foreign $R \& D$ was doubled, but only by one third if the same was to be done to domestic R\&D.

The results on innovation largely extend to labor productivity (see Appendix Table III.2). The coefficients on foreign $R \& D$ are again statistically significant and increase as the focus shifts from spillovers to followers to the ones among technological leaders, while the opposite is true for the coefficients on domestic R\&D. Also similar, how technological leaders are defined and whether the Chinese R\&D numbers are rescaled makes very little difference. One notable 
difference is that the magnitude of all the coefficients has become smaller, suggesting that productivity is less sensitive to $R \& D$ spending than innovation. However, the effect remains quantitatively important.

Appendix Table III.2: Labor Productivity as a Function of Domestic and Foreign R\&D

(1)

\begin{tabular}{lcc} 
& Followers & Top \\
Foreign R\&D & $0.0643 * * *$ & 0.146 \\
& $(3.57)$ & $(2.47)$ \\
Domestic R\&D & $0.136 * * *$ & 0.0389 \\
& $(6.72)$ & $(0.73)$ \\
\hline Country-Year FE & Yes & Yes \\
N & 3251 & 910 \\
R2 & 0.813 & 0.584 \\
\hline
\end{tabular}

(2)

Top 5

(2.47)

0389

$0.73)$
(3)

Top 7 - raw

$0.139 *$

(1.83)

0.0939

(1.38)
(4)

Top 7 - stock

$0.140^{*}$

(1.80)

0.0776

(0.99)
(5)

Top 7 - flow adjusted

0.144 *

0.0736

(0.96)

Note: The table shows coefficients and t-statistics of a panel regression with country-year fix ed effects. All regressions exclude the coke and petroleum sector. Top 7 regressions additionally exclude the wood and plastic sectors given missing da ta for China. Followers in column (1) are all countries excluding the Top 7. Va riables a re in na tural loga rithms. Standard errors are clustered at the country-industry level. ${ }^{*} \mathrm{p}<0.10,{ }^{* *} \mathrm{p}<0.05,{ }^{* * *} \mathrm{p}<0.01$ Source: Authors' calculations

To illustrate the magnitude of the effect, Appendix Figure III.2 shows the plausible contribution of knowledge spillovers among technological leaders to their annual labor productivity growth, as laid out in equation (2). The solid red bar (CHN-st.a.) shows results based on Chinese R\&D numbers, which are rescaled to match the other leaders' research productivity in terms of their patent stocks. The red dash shows the additional effect if $P A T_{l, i, t}$ in equation (3) reflects the annual patent flow. Finally, the red empty bar shows the implausibly large effects based on the actual R\&D numbers (CHN-u.a.).

\section{Appendix Figure III.2: Knowledge Spillovers' Contribution to Labor Productivity \\ (average implied contribution per year, in percent of GDP)}

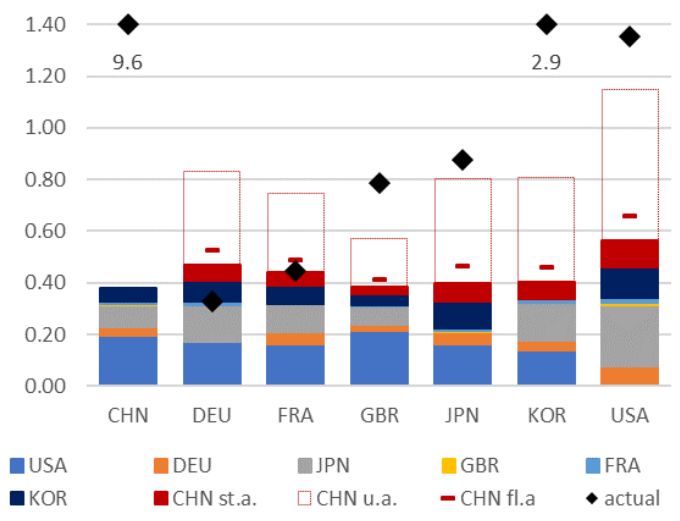

Note: The figure shows theimplied contribution from knowledge spillovers of the different technological lea ders to the annual la bor productivity growth in the country on thex-axis. Sources: OECD ANBERD and a uthors' calculations. 


\section{Appendix IV. The Empirical Gravity Model for Accessibility Weights}

This appendix reports and briefly discusses the results of the empirical gravity model used to calculate the "accessibility" weights $\varphi_{c, l}$.

As discussed in more detail in Eugster and others (2018) and Peri (2005), the weights $\varphi_{c, l}$ are constructed from a gravity regression of citations to patents associated with technological leaders. Patent citations are modelled as an exponential function of a set of dummy variables that indicate whether the citations involve two distinct countries (diff. country), whether these share a common border (diff. border) or an official language (diff. lang.) and how far the two countries are away from each other geographically (dist.int.) and in terms of technological specialization (tech. spec.) and development (tech. dev.). All variables are defined such that they are zero if the citing and cited country-sector are the same. Using the subscripts $c, l$, and $i$ respectively for the citing country, the cited country and the common industrial sector, the following model is estimated:

$$
\begin{gathered}
\varphi_{c l i}=\exp \left[a+f_{c i}+f_{l i}+b_{1} \text { (diff. country) }+b_{2} \text { (diff. border) }+b_{3} \text { (diff.lang. }\right) \\
\left.\left.\left.+b_{4} \text { (dist. int. }\right)+b_{5} \text { (tech. spec. }\right)+b_{6}(\text { tech. dev. })+\epsilon_{c l i}\right]
\end{gathered}
$$

The two country-sector fixed effects respectively for the cited $\left(f_{l i}\right)$ and citing country $\left(f_{l i}\right)$ control for the rate of patenting in both countries and institutional and cultural factors that affect the propensity to patent and cite. One appealing aspect of this setup is that the predicted value of $\hat{\varphi}_{c l i}$, excluding the constant and the fixed effects, is always equal to one if the citation happens within a given country-sector. In such a situation, all explanatory variables would be equal to zero and produce $\hat{\varphi}_{l l i}=\exp [0]=1$ independently of the coefficients $b_{n}$. This is a natural upper bound of the "accessibility" of the existing knowledge. The predicted value of $\hat{\varphi}_{c l i}$ if the citing and cited country thus reflect how accessible newly created knowledge is compared to the situation, where this is created domestically. 
Appendix Table IV.1 reports the estimated results of the $b_{n}$ coefficients. They are largely in line with the ones reported in Table 1 of Eugster and others (2018), with the expected negative sign and - with the exception of distance and contiguity - highly statistically significant.
Appendix Table IV.1: Barriers to

Knowledge Flows

Dependent Var.: Bilateral Citations

diff.country $-0.461 * * *$

\begin{tabular}{lc} 
& $(-3.83)$ \\
diff.next. & -0.217 \\
& $(-1.86)$ \\
diff.lang. & $-0.875 * * *$ \\
& $(-12.16)$ \\
dist.int. & -4.734 \\
& $(-0.41)$ \\
tech.spec. & $-2.282 * * *$ \\
& $(-3.30)$ \\
tech.dev. & $-0.253 * * *$ \\
& $(-6.81)$ \\
\hline $\mathrm{N}$ & 3447 \\
R-sq & 0.997
\end{tabular}

Note: Coefficients and t-statistics of gra vity regression of bilateral citations with Top 7 as cited countries. Standard errors are robust and clustered at the citing country-industry level. ${ }^{*} p<0: 10,{ }^{* *} p$ $<0: 05$ and $* * * p<0: 01$. Constant and fixed effects not reported. 


\section{References}

Anderson, D., B. Hunt, M. Kortelainen, M. Kumhof, D. Laxton, D. Muir, S. Mursula, and S. Snudden, 2013, "Getting to Know GIMF: The Simulation Properties of the Global Integrated Monetary and Fiscal Model," International Monetary Fund, IMF Working Paper 13/55.

Bown, C., 2020, "How Trump's Export Curbs on Semiconductors and Equipment Hurt the US Technology Sector," Peterson Institute for International Economics, September 28, 2020.

Caceres, C., D. Cerdeiro, and R. Mano, 2019, “Trade Wars and Trade Deals: Estimated Effects Using a Multi-Sector Model," International Monetary Fund, IMF Working Paper 19/143.

Cai, J., A. M. Santacreu, and N. Li, 2017, "Knowledge Diffusion, Trade and Innovation Across Countries and Sectors," FRB St. Louis Working Paper No. 2017-29.

Caliendo, L., R. Feenstra, J. Romalis and A. Taylor, 2017, “Tariff Reductions, Entry, and Welfare: Theory and Evidence for the Last Two Decades," CEPR Discussion Paper DP10962.

Chen, S. and E. Dauchy, 2018, "International Technology Sourcing and Knowledge Spillovers: Evidence from OECD Countries," International Monetary Fund, IMF Working Paper 18/51.

David, P., 1985, "Clio and the Economics of QWERTY," American Economic Review, 75(2): 332-337.

Eugster, J., G. Ho, F. Jaumotte and R. Piazza, 2018, "International Knowledge Spillovers," International Monetary Fund, IMF Working Paper 18/269.

Garcia-Macia, D. and R. Goyal, 2020, "Technological and Economic Decoupling in the Cyber Era," International Monetary Fund, IMF Working Paper 20/257. 
International Monetary Fund (IMF), 2018a, "Is Productivity Growth Shared in a Globalized Economy?" in World Economic Outlook, April 2018: Cyclical Upswing, Structural Change (April, Washington, D.C.)

,2018b, "Scenario Box 1: Global Trade Tensions" in World Economic Outlook, October 2018: Challenges to Steady Growth (October, Washington, D.C.).

, 2018c, "Asia and Pacific Background Paper No. 2-The Evolving Role of Trade in Asia: Opening a New Chapter," in Regional Economic Outlook, Asia and Pacific-Asia at the Forefront: Growth Challenges for the Next Decade and Beyond (October, Washington, D.C.).

Kumhof, M., D. Laxton, D. Muir, and S. Mursula, 2010, "The Global Integrated Monetary and Fiscal Model (GIMF) - Theoretical Structure," International Monetary Fund, IMF Working Paper 10/34.

Lenzen, M., D. Moran, K. Kanemoto, and A. Geschke, 2013, "Building EORA: A Global MultiRegion Input-Output Database at High Country and Sector Resolution," Economic Systems Research, 25(1): 20-41.

Organization for Economic Cooperation and Development (OECD), 2011, "ISIC Rev. 3

Technology Intensity Definition,” OECD Directorate for Science, Technology and Industry, Economic Analysis and Statistics Division, available at https://www.oecd.org/sti/ind/48350231.pdf.

Peri, G., 2005, "Determinants of Knowledge Flows and Their Effect on Innovation," Review of Economics and Statistics, 87(2): 308-22.

U.S. Chamber of Commerce, 2021, "Understanding U.S.-China Decoupling: Macro Trends and Industry Impacts," February 17, 2021. 
U.S.-China Business Council, 2021, "Decoupling with China Not Economically Viable for Americans,” Press Release, January 14, 2021.

Webster, G., Y. Luo, S. Sacks, N. Wilson, and A. Coplin, 2020, "Mapping U.S.-China Technology Decoupling' White Paper, Stanford FSI publications. 